資 料

水道水中の塩素の蚊幼虫殺虫試験 に与える影響 (予報)1)

\section{Preliminary report on the effect of chlorine in tap-water to the insecticidal activity of mosquito larvicides}

\author{
鈴杰猛2) \\ Takeshi Suzuki
}

蚊の幼虫の室内殺虫試験においては，シヤーレやビー カ一に，乳剤の希釈液を入れるか，あるいは，水中に殺 虫剤のアルコール（あるいはアセトン）溶液を滴下かく はんし，この中に幼虫を放ち，24時間後に死亡率を求め る方法が，もつとも普通に行なわれている.

この場合, 試験に使用する水としては, 特に厳密な規 定がなく，従来は，水道水をそのまま，使用する例が多 かつた

WHOの，蚊の幼虫の抵抗性を調ベる試験法には，使 用する水について，次の如く述べている.（Ano. 1960）

This water may be distilled, rain, well, stream, or tap-water, as free as possible of chlorine or organic contaminants. It should be noted that distilled water obtained commercially may contain traces of poisonous heavy metals.

筆者らは，蚊の幼虫の試験に，従来は，原則として， くみたての水道水をそのまま用いてきた.

その結果, アカイエカの幼虫に対する Baytex のLC50 として，0.26ppm といら值を得た。（水谷，鈴木， 1962).これは, Ramakrishnan et al. (1960) の 0.003 ppm, Jung et al. (1960) の 0.004ppm に比較して著し く高かつた。なお，水谷は，奄美大島において，採集し たアカイエカについて, 全く同じ方法で Baytex のLC-

1) This investigation was supported by a PHS research grant E-3328(R1) from National Institute of Allergy and Infectious Diseases, NIH, Public Health Service. Rp. No. 15.

2) 東京大学伝染病研究所寄生虫研究部 (主任 佐々学教授)

Department of Parasitology, Institute for Infectious Diseases, University of Tokyo (Chief : Prof. Manabu Sasa)
50 を求めて $0.003 \sim 0.004 \mathrm{ppm}$ の值を得ており，これが 果して colony の差によるものかどうか疑問のままに， 1961 年の衛動東日本支部大会に報告した（水谷, 平社, 鈴木, 1961).

その後, 奄美大島のアカイエカの colony を伝研にも ちかえり，数代の累代飼育後にテストした結果，伝研の アカイエカと同様に，0.1 0.3ppm という LC-50值を 得た.

このため，使用した乳剤中の有効成分量や，実験時の 水温や，また，観察までの時間など，試験の結果に変動 を与える要因について，検討を加えつつあつたが，1962 年 7 月になつて，この効力の差違は，使用した水の質に 由来することがわかつた．これらの詳細については，現 在なお検討中であるが，とりあえず，現在までに得られ たデ一タについて，佊として報告する。

まず，くみたての水道水 $200 \mathrm{cc}$ 中に, 各濃度の Baytex アルコール溶液 $0.8 \mathrm{cc}$ を滴下し, かくはん後にアカ イエカ $3 \sim 4$ 令幼虫を放ち，24時間後に死亡率を観察し た結果では，Baytex 0.4ppm で 100\%，0.2ppm で94.0 $\%, \quad 0.08 \mathrm{ppm}$ で $48.0 \% ， 0.04 \mathrm{ppm}$ で $2.0 \%$ となり， LC-50 は，およそ $0.08 \mathrm{ppm}$ である. 蒸留水を用い，全 く同じ操作で同時に行つた試験では，0.004ppm で100 $\%, 0.002 \mathrm{ppm}$ で $50.0 \%, 0.0008 \mathrm{ppm}$ で $0 \%$ となり， LC-50 はおよそ0.002ppm と考えられる.この值は，さ きに述べた Ramakrishnan et al., あるいは Jung et al. のデータと，かなりよく一致する.

なお，ここに用いた水道水中の $\mathrm{Cl}_{2}$ をオ一ヤ式簡易塩 素測定器で比色定量した結果，1.0ppm であることがわ かつた. Baytex は， $\mathrm{Cl}_{2}$ によつて酸化され，分解され やすいとされており,恐らく,水道水中の $\mathrm{Cl}_{2}$ が Baytex に作用してこれを分解し，効力の低い物質を生成したも のと考えられる.

なお，同様なアルコール溶液滴下法によつて，他の各 種殺虫剂の試験も行つたが, diazinon と malathionに おいては，Baytex と同様に，蒸溜水を用いた場合に， 水道水によつた場合に比較して，1/2〜1/4の LC-50 值が 得られているが，その開きは，Baytex の場合ほど大き くはない，塩素剤の場合は，蒸溜水と水道水のどちらを 用いても，効力にほとんど差が認められないようであ る.

この問題については，現在さらに検討を加えつつあり いずれ詳細を報告する予定である。

水道水中の $\mathrm{Cl}_{2}$ によつて 殺虫有效成分が 分解するこ とから，単に室内殺虫試験の場合に限らず，実地使用面 における影響も考えられる。すなわち，乳剤の希釈にあ たつては，井戸水やくみおき水を利用しにくい場所で 
は，水道水を用いるのが普通であるからである。しか

し，高濃度の乳戍などを水道水で希勫する場合，すなわ ちBaytexの量に比較して $\mathrm{Cl}_{2}$ の量が著しく少ない場合 には，分解される量はきわめて少量にとどまるため，効 力減少はさほど問題にならないであろう。

\section{引用文献}

1) Anonymous (1960): Insetcicide resistance and vector control. WHO/Insecticides/103, Annex. 2. -2) Jung, H. F., Kükenthal, H. \& Technan, G. (1960)：新防度殺虫唷Baytex (S 1752, Bayer 29493) について. Höfchen-Briefe 13(1) : 1-22. -3) 水谷 澄，平社俊之助，鈴木狧 (1961)：蚊の成虫扔上び幼

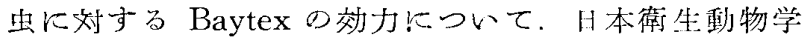
会第 13 回東日本支部大会講演，1961 年 10 月。－4） 水谷澄，鈴木猛（1962）：アカイエカと刘する各種殺 虫放の效力比較。衛生動物， 13 (1) : 56-63. -5) Ramakrishnan, S. P., Sharma, M. I. D. \& Kalra,
R. L. (1960) : Laboratory and field studies on the effectiveness of organophosphorus insecticides in the control of Culex fatigans. Ind. J. Mal. 14 : 545566.

\section{Summary}

For assessing the effect of insecticides to mosquito larvae, the dipping method would widely be adopted. In these tests, the LC-50's of Baytex given in the author's laboratory was extremely diverse ; in one case it was approximately $0.2 \mathrm{ppm}$, and in the other case it was 0.002 to $0.004 \mathrm{ppm}$. After some researches aiming the reason, the author was led to the conclusion that chlorine in tap-water used in the tests oxidized Baytex to some materials far less effective than the former compound. The detail will be reported in the near future in English.

\begin{tabular}{ll}
\hline 会 報 \\
\hline
\end{tabular}

第14回日本衛生動物学会 東日本支部大会

封 1962 年 10 月 21 日

所静岡市中央公民館

会長 須川豊博士（静岡県衛生部長）

議事 次期会長・会場が次の通り決まつた。 会屒 矢島朝彦博士

会場 農林省家音衛生試験場

\section{特 别講 演}

\section{「渡米みやげ話」}

東大伝染病研究所寄生虫部 林 滋生 博士

\section{一般 講 演}

1. Aedes (Finlaya) koreicoides の成熟幼虫の口

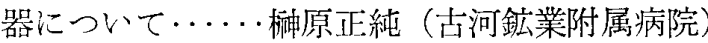

2. 東京産アカイエカ上奄美大島産アカイエカとの 交配成績について・.山口昇（東女医大・寄生虫）

3. 水田の蚊幼虫に対する農薬散布の役割…… ○緒方一喜(予研昆虫), 中山孝夫（小崎・高津 保健所)

4. 水道水に含まれる塩素の蚊幼虫殺虫試験に与え
る影響…ㅇ鈴木猛，松永秀子，海野登久子， 水谷澄（伝研寄生虫）

5. オウクロヤブカ，トウゴウヤブカ，ヒトスジシ マカなどに対する殺虫剂の効力……...... 水谷澄，○鈴木猛，松永秀子（伝研寄生虫）

6. 各種形態の殺虫剤のアカイエカに対する効力. ○海野登久子, 水谷 澄, 松永秀子, 鈴木 猛 （伝研笴生虫）

7. アカイエカ幼虫に対する殺虫剂の希釈溶液と処 理力法の違いによる效力の変動について…… ○平社俊之助（伝研寄生虫, 中央化学)

8. アカイエカ幼出室内殺虫試験の基礎的検討 .... 松永秀子, 平社俊之助, 栗原毅, 鈴木猛（伝研 等生虫)

9. 東京都千代田区内に打ける八エ類の季節的消長 ○加納六郎，金子清俊，宮本健司，織内実子 (東医歯大・医動物)

10. デイプテレックス散布による八エ駆除野外実験

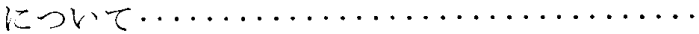

○大滝哲也（埼玉衛研），桑原豊吉（埼玉 - 春 日部保健所)

11. 抵抗性イエバエに対するスミチオンのフイール ド実験 $\ldots \ldots \ldots \ldots \ldots \ldots \ldots \ldots \ldots \ldots \ldots \ldots \ldots$ ○安富和男 (予研昆虫), 中山茂, 传々木精一, 岩原保 (茨城県環衛課), 飯塚勝己, 椎名忠夫, 松村友夫 (土浦保健所)，糸賀吉雄 (美浦村役場)

12. 抵抗性イエバエの駆除実験 $\ldots . . . \ldots \ldots \ldots \ldots$ 安富和男(予研昆虫), 中山茂, 佐々木精一, 